Steven Paget

Forthcoming in Small Wars and Insurgencies, 28:2, 2017. This is the post-print version and must not be copied or cited without permission.

\title{
'A Sledgehammer to Crack a Nut'? Naval Gunfire Support during the Malayan Emergency
}

\begin{abstract}
Apart from an element of surprise warships provided little more than convenient gun platforms and their employment as mobile artillery was subject to the limitations of all offensive shelling in the Malayan campaign: imprecise coordinates and an uncertainty which way the guerrillas would move which made it a matter of harassment rather than destruction. ${ }^{1}$
\end{abstract}

David Ucko has observed: 'In the haste to draw lessons from this exceptional campaign, the Emergency has tended to be over-farmed for useful parallels, some of which show scant regard for the campaigns specificity and content.' ${ }^{2}$ The 'specificity' of the Emergency must be taken into consideration as some of the elements of the conflict were unique to Malaya, but that does not mean that there are not lessons to be gleaned if they are understood in context. In 2006, Harry Miller posed the question as to whether the force massed against the Malayan Races Liberation Army (MRLA) represented 'a brick to crush an ant' ${ }^{3}$ While that issue is debatable, the same question could be asked about the use of naval gunfire support (NGS). NGS is an oft-derided and misunderstood capability. Its merits have been regularly questioned and perhaps never more so than during the Malayan Emergency.

In assessing a bombardment by HMA Ships Queenborough and Quickmatch in January 1957, Peter Dennis and Jeffrey Grey opined: 'naval power was inappropriate to the circumstances of the Malayan Emergency'. At first glance, the lesson about NGS might appear to be that it was unsuitable - akin to using a sledgehammer to crack a nut - or, at the very least, used excessively. The challenges presented by operating in an environment dominated by dense jungle and against an enemy that was relatively small numerically and elusive by nature reduced the frequency with 
Steven Paget

Forthcoming in Small Wars and Insurgencies, 28:2, 2017. This is the post-print version and must not be copied or cited without permission.

which NGS was required and, sometimes, the effect that could be achieved. However, when enemy forces could be contained or flushed into the open or when other forms of fire support were not available, NGS demonstrated a usefulness that exceeded the conventional wisdom about its efficacy in Malaya.

The utility of firepower during insurgencies has been a contentious issue with some analysts pointing to a perceived 'hyperfocus on firepower and killing the insurgent enemy' ${ }^{5}$ The Vietnam War has dominated much of the discussion, but the Malayan Emergency remains hotly debated. The majority of scholarly attention has centered on the provision of firepower by the Royal Air Force (RAF) and Commonwealth air forces, which remains 'controversial' ${ }^{6}$ NGS has been less controversial, but that is because it has largely been dismissed. Firepower is not and never will be a silver bullet in combating insurgency. Indeed, as James Corum has written: 'A counterinsurgency strategy that relies overwhelmingly on military forces and military operations - and ignores the social, political, and economic aspects of the insurgency-will not lead to the desired endstate or even close to it. ${ }^{7}$ As a result, in most cases, the provision of firepower is only a minor consideration to accomplish a limited mission. However, firepower has fulfilled an important role in the past and it is incumbent on militaries to utilise every instrument at their disposal when they can be used effectively. Although NGS may have only proven useful under certain circumstances, similar situations have arisen in both earlier and later conflicts. While it is easy to dismiss the utility of NGS, the capability has been effective in the past and remains relevant in the contemporary operating environment. 
Steven Paget

Forthcoming in Small Wars and Insurgencies, 28:2, 2017. This is the post-print version and must not be copied or cited without permission.

\section{Naval Gazing: Recognition of the Maritime Counterinsurgency Role}

Sadly, the Navy's role is not well understood because many who discuss irregular warfare wear 'cammies' and emphasize ground-centric perspectives. ${ }^{8}$

Sinclair Harris

Counterinsurgency has become a vogue topic, but the maritime aspects have been under-examined. Land power remains the principal focus of studies of the military aspects of counterinsurgency campaigns. The notion that 'small wars and counterinsurgencies are won or lost by the troops on the ground', prompted Andrew Mumford to note that it is 'to the army that we usually turn to understand victory or defeat'. ${ }^{9}$ The traditional focus is not unfounded because as Corum reminds us: 'Counterinsurgency is inherently land-centric because it is about populations, and populations live on the land. ${ }^{10}$ Furthermore, while 'insurgency can take place at sea (and along coasts and rivers)', Martin Murphy has pointed out that it always has 'the aim of achieving effect on land'. ${ }^{11}$

The supporting roles played by air and naval forces has led to concomitantly fewer studies of their contributions, although there has been a surge in air power studies over the past two decades. Counterinsurgency operations have been interwoven into air power histories and theory since their emergence given that 'almost from the moment the airplane was invented...Western powers found it to be an exceptionally useful weapon for fighting rebellious tribesmen in the colonies' ${ }^{12}$ The perception that air power could potentially be a panacea to economic, logistic and manpower constraints has ensured that it has received greater scholarly attention than the naval role.

The relative dearth of studies on the maritime aspects of counterinsurgency operations can be attributed to a range of factors. The phenomenon known as 'sea blindness' - the failure of 
Steven Paget

Forthcoming in Small Wars and Insurgencies, 28:2, 2017. This is the post-print version and must not be copied or cited without permission.

politicians, the media and the public to understand the significance and use of the sea - has been the subject of much debate. ${ }^{13}$ Without delving into the nuances of 'sea blindness', the limited attention devoted to the maritime element of counterinsurgency can be viewed as a reflection of a broader trend. ${ }^{14}$ In addition, larger western navies have tended to prioritise blue water over green and brown water capability. The cumulative result has been an under-estimation of the maritime contribution to counter-insurgency. The neglect of the naval side can also be attributed, in part, to the attention devoted to recent operations in Afghanistan and Iraq where the naval role has been somewhat less visible than the air and land contributions.

The significance of naval forces is also often overlooked as insurgent groups generally have limited maritime capacity in comparison to their opposition. In particular, the absence of significant naval combat capability on the part of insurgents has tended to keep the focus on land forces. However, when counterinsurgency operations have confronted a significant maritime threat, the importance of naval forces has been highlighted. Bruce Hoffman has emphasised that the Liberation Tigers of Tamil Eelam (LTTE) had 'its own blue-water navy, with ocean-going cargo vessels alongside a formidable array of riverine (brown water) and coastal (green water) attack craft'. ${ }^{15}$ Additionally, the LTTE employed underwater assets, mines and suicide boats to target Sri Lankan Navy vessels. ${ }^{16}$ In 2007, it was recorded that since its formation in 1984, the LTTE had destroyed 'between a third and a half' of the Sri Lankan Navy's coastal fleet and had conducted piracy against commercial vessels. ${ }^{17}$ The Sri Lankan experience demonstrated that it is complacent to dismiss or overlook the significance of the maritime role in counterinsurgency. ${ }^{18}$

An argument could also be made that maritime counterinsurgency roles have sometimes been overlooked as they have been mislabelled. In reassessing the political agitation of Daniel 
Steven Paget

Forthcoming in Small Wars and Insurgencies, 28:2, 2017. This is the post-print version and must not be copied or cited without permission.

O'Connell's 'Repeal Association', which peaked in 1843, and the 'Young Ireland' rising of 1848, Jerome Devitt contended that the Royal Navy's mission 'fell outside the traditional view of naval/gunboat diplomacy, and is better described as having a naval counter-insurgency role' ${ }^{19}$ In addition, while the contrast between conventional and counterinsurgency operations can be vast for land forces, the differences can be more subtle for maritime forces. For example, although the scale of the challenge may differ, blockades conducted during counterinsurgency operations are broadly similar to those implemented in conventional conflicts. The significant amount of overlap between roles during conventional and counterinsurgency operations should not cloud their importance.

Paradoxically, the strengths of maritime forces can shroud the significance of their contribution. The flexibility of naval forces and their inherent ability to transition between roles can create the impression of a lack of specialism in counterinsurgency. Equally, the limited 'political and diplomatic footprint ashore in comparison to land-based forces' can be extremely useful in minimising local resentment, placating neighbouring nations and reducing the risk of casualties, but it can lead to maritime forces becoming a footnote in the popular narrative of insurgencies. ${ }^{20}$ The issue is compounded by the fact that a number of naval roles lack the popular appeal of operations that deliver kinetic effect. Blockades, for example, are regularly described as involving 'long periods of monotony' and being 'slow' and 'boring', while re-supply operations are 'not glamorous'. ${ }^{21}$ They may not be glamourous, but operations that shape the battle space are crucial to those operating ashore.

Ironically, the lack of awareness about the maritime contributions to counterinsurgency operations has created a platform for increased involvement. In proposing that there is likely to be 
Steven Paget

Forthcoming in Small Wars and Insurgencies, 28:2, 2017. This is the post-print version and must not be copied or cited without permission.

an 'Iraq syndrome' akin to 'Vietnam syndrome', James Kurth suggested that the 'very reaction of the American public against ground combat operations may strengthen the Navy's case for naval combat operations' as 'maritime counterinsurgency is likely to issue in far fewer casualties'. ${ }^{22}$ Geography has also been an important determinant in the significance of the maritime contribution to counterinsurgency operations. While the potential of maritime forces could not be fully realised during operations in Afghanistan and Iraq, the future conduct of operations in areas that are more susceptible to naval power should not be underestimated. Ultimately, maritime forces have always made invaluable but unheralded contributions to counterinsurgency operations. Given the ongoing and, potentially, increasing contribution of naval forces it is essential that all aspects of the maritime role are understood.

\section{The Naval Contribution to the Malayan Emergency}

The opportunities for vessels of the Royal Navy to participate in the operations are limited, but those which do present themselves are rapidly exploited. ${ }^{23}$

Review of the Emergency Situation in Malaya at the End of 1954

The Malayan Emergency, which stretched from 1948 to 1960, pitted Commonwealth forces against the MRLA or Communist Terrorists (CTs) as they were often called by the security forces. John Coates has written: 'The contribution which the navy could make to the Emergency was necessarily limited. ${ }^{, 24}$ From the military perspective, this was very much an infantryman's conflict. Nevertheless, air and naval forces made varied and useful contributions to the successful outcome. ${ }^{25}$ Tim Benbow has noted 'maritime forces had a significant supporting role that belies their usual neglect', while Chris Tuck described the RN's efforts as 'an important, though subsidiary, contribution to operations' ${ }^{26}$ 
Steven Paget

Forthcoming in Small Wars and Insurgencies, 28:2, 2017. This is the post-print version and must not be copied or cited without permission.

According to The Conduct of Anti-Terrorist Operations in Malaya, the RN contributed to the Malayan Emergency by conducting 'anti-smuggling and anti-piracy patrols', 'amphibious landings' and 'bombardment of CT areas' ${ }^{27}$ Other Commonwealth ships played an analogous role, with the directive to the Commander-in-Chief, Far East Station, asserting that Royal Australian Navy (RAN) ships could be 'used as for ships of the Royal Navy in Malayan waters to prevent infiltration by Communist agents or armed bandits by sea together with anti-terrorist operations in Malaya'. ${ }^{28}$ In addition, the Fleet Air Arm's medium S-55 helicopters were 'invaluable' in increasing the tactical mobility of Commonwealth forces. ${ }^{29}$ Indeed, between 1954 and 1956, the Naval Air Squadrons reportedly undertook the 'major part of the troop-lifting'. ${ }^{30}$ Infrequent air strikes were also conducted from aircraft carriers visiting the area; normally on their way to or from Korean War operations.

Alongside the Royal Malayan Navy and Police, the fundamental role played by Commonwealth naval forces and RAF flying boats was the conduct of coastal patrols. ${ }^{31}$ The imposition of a blockade offered the potential to seal off Malaya on three of four sides, with only the northern border with Thailand presenting an overland infiltration route. Consequently, the surveillance of the coast was afforded great significance. Over 1,000 craft were searched during 1952 alone. $^{32}$ Although the threat posed by seaborne infiltration remains questionable, the 'constant but unspectacular' blockade applied a stranglehold on the insurgents in Malaya. ${ }^{33}$ Subsequent evaluations have determined that no men or materiel were infiltrated by sea during the Malayan Emergency. ${ }^{34}$ The coastal patrols also offered an opportunity to 'show the flag', although as one historian noted, the effects of such activities are 'difficult to quantify'. 35 
Steven Paget

Forthcoming in Small Wars and Insurgencies, 28:2, 2017. This is the post-print version and must not be copied or cited without permission.

Despite the frequent focus on the role of helicopters, the troop landing role performed by naval vessels was significant due to the nature of the operating environment. While these landings were 'occasionally coastal', they were often riverborne operations, with troops being transported by landing craft and launches. ${ }^{36}$ Notably, the so-called Malayan Scouts - the Special Air Service (SAS) - were deployed by naval forces in south-east Pahang during Operation Prosaic in 1951 as part of a 'deep jungle penetration' mission. ${ }^{37}$ The capacity to deploy land forces from ships was extremely useful due the coastal nature of the operating environment and the extensive river network.

Naval bombardment - or NGS - played a more prominent role than is sometimes credited. Accounts often recite that 39 bombardments were conducted in 1952, but the contributions throughout the remainder of the Malayan Emergency are regularly overlooked. A review of the Malayan Emergency from 1948 to 1957 observed that the RN had 'assisted many operations by coastal bombardment'. ${ }^{38}$ Exact numbers of bombardments throughout the Emergency are difficult to precisely pinpoint, but the figure is much higher than is often acknowledged. For example, in 1955, a further 24 bombardments were conducted. ${ }^{39}$

The frequency of bombardments fluctuated throughout the Malayan Emergency depending on the situation on the ground. Grey has assessed that bombardments were used most frequently in the first years of the insurgency when 'the MRLA was most active and most effective and at a time when the security forces' own resources were most thinly stretched'. ${ }^{40}$ As coastal areas were cleared, bombardment requests dropped concurrently. In 1956, there were just three bombardments and it was noted that there had been 'little call' for naval gunfire 'with most coastal areas white'. ${ }^{41}$ Notably, naval vessels made use of the rivers to provide NGS further inland. HMS 
Steven Paget

Forthcoming in Small Wars and Insurgencies, 28:2, 2017. This is the post-print version and must not be copied or cited without permission.

Amethyst travelled 30 miles up the Perak River to bombard a suspected CT camp in 1952, while HMS Defender conducted a shoot nine miles up the Johore River in $1954 .^{42}$ In early 1956 , the Director of Operations, Malaya, summarised: 'Bombardment of the terrorists by ships is a most helpful form of support for ground operations, but unfortunately there are not many opportunities for this type of attack. ${ }^{43}$ However, limited opportunity did not always equate to limited utility.

\section{NGS: A Destructive or Harassing Capability?}

While the nature of the operating environment inevitably limited the provision of NGS, it was used extensively during some operations. For example, during Operation Nassau, five ships fired 346 6", 1,307 4.5" and 1904 " rounds, as well as 30 Starshells. ${ }^{44}$ In fact, between Operations Nassau and Rex, all but three ships of the Far East Fleet conducted live bombardments. ${ }^{45}$ There has been an overriding sense that NGS was not overly well coordinated, with one work positing that at least two accounts concluded that: 'the absence of effective shore control, spotting and target coordinates resulted in missions that were non-specific "harassment" rather than effective “interdiction". ${ }^{46}$ However, while NGS was often used in a harassment role, the intended purpose was a lot more diverse than has often been credited. In particular, effective interdiction and accurate destructive bombardments were possible when Army Auster aircraft, which undertook the roles of 'target marking' and spotting, were available. ${ }^{47}$

The capacity of the MRLA to move further inland and evade NGS limited its usefulness on many occasions. However, when the enemy could be contained in a particular area, NGS had the potential to be extremely effective. During Operation Rex, which was conducted on the Penggerang peninsula between March and August 1955, the 9th Independent Platoon, MRLA, was penned in through a combination of geography and ground activity. Although the platoon only 
Steven Paget

Forthcoming in Small Wars and Insurgencies, 28:2, 2017. This is the post-print version and must not be copied or cited without permission.

consisted of approximately 25 'well armed and well led' members, they were reported to have had 'high morale' and have been 'actively aggressive' in the Kota Tinggi and Penggerang districts. It was recorded: 'R.N. and R.A.F. bombardment was found by the Army to be invaluable in this area of extremely difficult going. Bombardments were planned to flush the enemy out of possible camping areas, and harass likely escape routes. ${ }^{48}$

NGS was conducted 'whenever possible' during the operation. ${ }^{49}$ The geography of the peninsula naturally lent itself to the provision of NGS. The whole target area was in range of the guns of the larger ships and most was within reach of the 4" and 4.5" guns of frigates and destroyers. NGS, in conjunction with air strikes, took on even greater significance due to the jungle environment, which was deemed too dense for the deployment of artillery inland. ${ }^{50}$ Point targets were specifically identified and observation by the RAF's 1911 Light Liaison Flight was provided for almost all of the daytime bombardments. ${ }^{51}$ An assessment of the operation by the Flag Officer, Malayan Area, concluded: 'Naval participation, with gunfire support, patrol and sea-transport, formed an integral part of Operation REX...without naval bombardments and coastal patrols, it is probable that the $9^{\text {th }}$ Independent Platoon would still be operating in the area. ${ }^{52}$

Bombardments conducted by HMS Newfoundland between 8 and 9 June 1954 achieved notoriety because they were delivered when the ship was diverted from her journey to participate in the Queen's birthday celebrations. The bombardments conducted by the ship provided an indication of the nature of NGS in Malaya. After being tasked with providing bombardments for security forces operating in Central Kedah, approximately 25 miles north of Penang, arrangements were made to facilitate the firings. One inch to the mile maps of the area were provided by the Flag Officer, Malayan Area, and communications with an air spotter were organised through the Naval Liaison Officer, Kuala Lumpar. The initial instructions designated five targets that each 
Steven Paget

Forthcoming in Small Wars and Insurgencies, 28:2, 2017. This is the post-print version and must not be copied or cited without permission.

comprised 1,000 square yards of dense jungle. Notably, the targets were at heights of 2,000 to 3,000 feet and two of them were on the reverse slope of Kedah Peak. The ship was instructed to provide harassing fire during designated windows consisting of two to three hours depending on the target. Newfoundland was also put on notice to bombard pinpoint targets if CT camps were detected by the air spotter. ${ }^{53}$

While the initial order called for harassing fire, reconnaissance of the target areas resulted in confirmation that some of them were 'live' (actively being used by the CTs). The ship engaged a number of targets across the course of two days. In one example, Newfoundland engaged a hut that was believed to be part of a CT camp with spotting being provided by Captain D. J. Browne, Royal Artillery, in an Auster aircraft. After initial corrections, Newfoundland was able to accurately engage the targets, with photographic reconnaissance later indicating two direct hits on the hut and two craters within five yards. It is popularly believed that NGS during the Emergency was somewhat haphazard. However, it is worth noting that while the shoot was punctuated by the ship visiting Penang harbour to enable elements of the crew to participate in the dress rehearsal for the Queen's birthday parade, it offered an opportunity for Captain Browne to visit Newfoundland and provide a report on the bombardments, as well as deliver a larger scale map for the shoots on the following day. A number of targets were successfully engaged, but the terrain and weather (particularly cloud cover) also demonstrated the limitations of NGS. During a bombardment of a camp area on 9 June, which was described as being 'very effective' following photographic reconnaissance, it was noted that while 'damage must have been done to the contents', complete destruction of a lean-to proved impossible due to the presence of tall trees. ${ }^{54}$

Over the course of the two days, 267 6" high explosive rounds were fired by Newfoundland. After assessing reports of the bombardments, the Second-in-Command, Far East Station, deduced 
Steven Paget

Forthcoming in Small Wars and Insurgencies, 28:2, 2017. This is the post-print version and must not be copied or cited without permission.

that the ship 'put up a good technical performance in these bombardments'. ${ }^{5}$ Indeed, 56 Ground Liaison Section, RAF Station Butterworth, declared: 'the bombardment was most successful and undoubtedly considerably harassed CTs who were known to be operating in the area West and South West of Kedah Peak at the time'. ${ }^{56}$ Perhaps most telling was a report by HQ 1 Federal Division District, Taiping, which stated:

Ground troops from A and D 5 MALAY followed up the bombardment by HMS NEWFOUNDLAND and found that all targets had been effectively engaged and destroyed. The reported camp...was an old mining kongai. This had received a direct hit from HMS Newfoundland. General comment by troops was that the shelling was hundred percent successful. ${ }^{57}$

The bombardment was noteworthy not just for its reported success, but also because the operation was spotted by the air and subjected to photographic reconnaissance and subsequent sweeps by ground forces.

Success was attributed, in part, to 'Captain Browne's most accurate and concise spotting', which was conducted under 'very trying conditions' ${ }^{58}$ In addition, although it was recommended that larger scale maps be issued to 'facilitate height estimation of pin point targets' in mountainous areas - a notion that received support from higher command - the provision of maps was crucial for the delivery of NGS. ${ }^{59}$ As a corollary, Captain E.H. Thomas, Newfoundland's Commanding Officer, reflected: 'This bombardment has been a very good tonic to the ship after many months with little or no chance to carry out practice firing. ${ }^{60}$ Newfoundland's activities demonstrated that when properly planned, focussed on appropriate targets, spotted, and subsequently assessed, NGS could be effective.

The involvement of RAN ships also provided a good indicator of the nature of NGS operations during the Emergency. The first bombardments were conducted by HMA Ships Anzac 
Steven Paget

Forthcoming in Small Wars and Insurgencies, 28:2, 2017. This is the post-print version and must not be copied or cited without permission.

and Tobruk on 29 September 1956 as part of a 'major security force operation' to drive approximately $400 \mathrm{CTs}$ from southern Johore. ${ }^{61}$ The targets for the bombardment were in the vicinity of Tanjong Balau and the shoot was facilitated by bombardment charts of the area that were dropped to both ships by Sunderland aircraft during the previous day. In addition, to preplanned targets, additional ones were designated by the Army Auster aircraft that provided spotting. ${ }^{62}$ Each ship separately engaged targets, before two additional ones were subjected to 'concentrated fire' from both vessels, leading to a report of 'most effective' shooting. ${ }^{63}$ Ian Pfennigwerth has since observed that the bombardment: "was not harassment shooting, and the spotter's presence suggests that there were clearly identified targets to be taken under fire'. ${ }^{64}$

On 22 January 1957, Queenborough and Quickmatch fired 40 rounds each at suspected CT positions in Southeast Johore. The targets taken under fire were a coconut grove, which was believed to be a source of supplies for the CTs, a nearby wooden bridge and a CT camp. The shoot was spotted by an Army Auster aircraft. ${ }^{65}$ Although the spotter noted that the camp may have been empty when it was hit, it was assessed that it was damaged and was 'unlikely' to be 'used for some time'. ${ }^{66}$ On the 25 July 1957, Anzac engaged four separate 'suspected terrorist positions' in Johore. The shoots were spotted by an observer in an Auster aircraft and while Anzac did not record the results of the bombardments, it was noted that 'good training value was obtained'. ${ }^{67}$ On 26 August 1957, Tobruk took seven targets under fire with the Auster aircraft that spotted the shoots reporting 'good results'. 68

The record of NGS was mixed during the Malayan Emergency. Inevitably, there was a degree of wastage and it was undoubtedly used inappropriately on occasion. Even when it did prove useful, the effect of NGS was never decisive. However, it did make valuable contributions 
Steven Paget

Forthcoming in Small Wars and Insurgencies, 28:2, 2017. This is the post-print version and must not be copied or cited without permission.

to the success of various operations. Ultimately, the effectiveness of NGS was situationally dependent. When it was directed at specific, intelligence-led targets and spotted to improve accuracy, as happened more often than is sometimes credited, NGS did have a role to play.

\section{NGS: A Psychological Weapon?}

The relevance of NGS during the Malayan Emergency has often been questioned on the basis of its purpose, particularly its use in the harassment role. However, as harassing fire is intended to keep the enemy off-balance and diminish morale, the psychological effect of NGS was significant. Parallels can be drawn to the conduct of aerial bombing in the context of psychological effect. In a letter from Sir Evelyn Baring to the Colonial Secretary on 5 December 1953, aerial bombing was justified on that basis that as well as casualties being inflicted 'on a number of occasions', strikes had 'a detrimental effect on the morale of enemy gangs'. ${ }^{69}$ Similarly, Colonel W.N. Gray, who became Police Commissioner in 1948, observed that air strikes had 'contributed more than any other factor to the number of bandit surrenders' ${ }^{70}$ The use of NGS, air power and artillery in the harassment role raises questions about efficiency, but the impact on enemy morale must be taken into consideration.

The psychological effect of NGS was never more apparent than during Operation Nassau, which was conducted in the Kuala Langat area with the intention of eliminating a local gang of CTs. ${ }^{71}$ As with all operations during the Emergency, the role of ground forces was fundamental to Nassau's success, but naval power contributed in a number of ways. When Nassau was initiated, 
Steven Paget

Forthcoming in Small Wars and Insurgencies, 28:2, 2017. This is the post-print version and must not be copied or cited without permission.

Commonwealth forces conducted bombardments with various weapons night and day. From 9 January to 20 August 1955 , the south swamp area was bombarded almost every night. ${ }^{72}$ Daytime bombardment was ceased in March 1955, but nightly harassing fire, as well as morning and evening 'hates' were conducted against specific targets. ${ }^{73}$ A summary of the operation noted:

Initially it was hoped that the effect would be to drive the C.Ts from the centre of the swamp into ambushes set around the edge. It is doubtful if this effect was ever achieved, but from information given by surrendered enemy personnel it is certain that night bombardments had a particularly lowering effect on the morale of the C.Ts. If shells or bombs fell uncomfortably close to a camp in the dark, it was found that C.Ts were in the habit of moving out, waiting until the bombardment stopped, and then moving back again. During night harassing fire, it was therefore the practice to re-engage targets which had already been bombarded. ${ }^{74}$

Interestingly, as the MRLA reportedly had difficulty distinguishing between the calibre of shells, smaller projectiles were able to have a disproportionate effect on morale. MRLA morale was considered 'very high' prior to the commencement of the operation, but the imposition of food control measures and 'continuous non-stop patrolling, harassing fire and psychological warfare' diminished their confidence until 'morale broke completely'. As a direct consequence, there was an increase in the number of surrenders from June onwards. ${ }^{75}$

The Flag Officer, Malayan Area's report to the Commander-in-Chief, Far East Station, assessed:

The aim of the operation, which was to destroy the M.C.P. [Malayan Communist Party] organisation in the Kuala Langat area, was fully achieved. Out of the 37 C.Ts in that area, 35 had either been killed, captured or had surrendered by the end of the operation. Although these eliminations fell to the ambushes and systematic searches of the Land Forces, bombardment by Sea, Land and Air Forces played a significant part in lowering morale. ${ }^{76}$

While naval power was not decisive in itself, the effect on the morale of the enemy, friendly forces and the civilian population was significant and contributed to the success of the operation. 
Steven Paget

Forthcoming in Small Wars and Insurgencies, 28:2, 2017. This is the post-print version and must not be copied or cited without permission.

Fire support of all forms aided the maintenance of and improvements in the morale of friendly forces. Robert Jackson contended: 'the presence of strike aircraft provided a great uplift to the morale of the troops on the ground, fighting an elusive and ruthless foe in an alien environment' ${ }^{77}$ While the presence of aircraft has a psychological effect that makes it distinct from other forms of firepower, the provision of NGS also helped to reinforce the idea that those fighting on the ground were being supported. In addition to undermining the morale of the enemy, 'hates' have always been intended to embolden and strengthen the resolve of friendly forces. ${ }^{78}$ The effect was no different in Malaya.

As well as improving the morale of those fighting on the ground, the provision of NGS was a huge boon for the crews of Commonwealth ships. During Operation Rex, the Flag Officer, Malayan Area, revealed: 'even an acknowledgement to the ship that the bombardment was effective' was 'a help to morale onboard'. ${ }^{79}$ Following Operations Nassau and Rex, the Commander-in-Chief, Far East Station, informed the Admiralty: 'The operations afforded facilities for live bombardment... with the resultant benefit to the morale of Ships' Companies that can be achieved only by participation in operational firings. ${ }^{80}$

Finally, the way that fire power was perceived by the friendly civilian population was also important. Although often only a 'secondary aim', as was the case during Operation Rex, bombardments were conducted with the stated intention of improving civilian morale. ${ }^{81}$ Analysts have noted that civilian morale was influenced through the use of air power with Jackson suggesting that the effect of air strikes was 'decisive' and that the demonstration of force 'persuaded many civilians to resist the terrorists and co-operate with the Security Forces' ${ }^{82}$ While civilian morale was hard to quantify, casual contemporary observations of NGS indicated that the 
Steven Paget

Forthcoming in Small Wars and Insurgencies, 28:2, 2017. This is the post-print version and must not be copied or cited without permission.

'long-term benefit' of 'raising...civilian morale is incalculable'. ${ }^{83}$ The psychological effect of NGS during the Malayan Emergency is sometimes overlooked by the focus on air power, but its influence on enemy, friendly and civilian morale should not underestimated.

\section{An Imperfect Asset: The Limitations of NGS}

The Malayan Emergency demonstrated that NGS is far from a perfect capability. One of the greatest limitations was that the MRLA did not provide a particularly opportune target in terms of their overall size, organisation or operating style. A 1948 assessment placed the number of armed members between 3,000 and 5,000. Although they were nominally organised into formations that resembled regiments, they frequently operated in groups of between 10 and 50 and sometimes even fewer. ${ }^{84}$ The MLRA's modus operandi also made the effective use of firepower difficult. Brigadier Dennis Talbot explained in 1950:

[B] andits are guerrillas who depend on hit and run tactics...[T] heir object is to avoid clashing with the security forces except when the latter are greatly outnumbered and taken by surprise...[T]hey do not defend or hold any particular area or function on a line of communication. ${ }^{85}$

The reluctance of the MLRA to stand and fight meant that engagements were often limited to small arms fire. From a sheer numerical perspective, the overall size of the MRLA and the fact that the insurgency was spread across Malaya meant that a bountiful selection of targets was never likely. Indeed, as the MRLA's numbers were whittled down through kills, surrenders and desertion, the amount of potential targets continued to diminish. Moreover, as the MRLA tended to operate in small groups and often relied on ambushes, there was a limit to what firepower could achieve - be it NGS, artillery or air power. 
Steven Paget

Forthcoming in Small Wars and Insurgencies, 28:2, 2017. This is the post-print version and must not be copied or cited without permission.

The 'seemingly all-concealing tropical jungle', which was nicknamed the 'green hell' by British troops, hindered the provision of firepower of all varieties. ${ }^{86}$ Not only did the CTs use the jungle to conceal their activities, but the operating environment sometimes acted as a barrier to the effective employment of NGS. The potential for the MRLA to intersperse themselves amongst the local populace also ensured that discrimination and restraint were necessary. The spread of fire from NGS meant that its use required careful consideration to avoid collateral damage.

As was the case with air power, the utility of NGS was very much dependent on the effectiveness of cooperation between the service branches. When spotting aircraft were not provided or were not available for various reasons (including weather), the likely utility of NGS was diminished. The much maligned harassment fire could be effective, but that was only the case when intelligence confirmed the ongoing presence of the enemy in the bombardment area.

The most successful bombardments were conducted in conjunction with coordinated ground activity. NGS and air strikes could be used to drive CTs from particular areas and into engagements with security forces. ${ }^{87}$ Moreover, follow-up operations were also important in helping to provide assessments of the damage done by bombardments. When coordination was effective, good results could be achieved, but when unity of effort was lacking, the potential of NGS was constrained. Despite the success of Newfoundland's bombardment in June 1954, it is notable that the Naval Liaison Officer at Headquarters, Malaya, lamented: 'It is unfortunate that the $1^{\text {st }}$ Malay Infantry Brigade which supplied the follow-up troops were withdrawn and sent to Taiping a few days after the operation. ${ }^{98}$ Jointness and coordination between the service branches was the key to the successful use of NGS.

\section{NGS during the Malayan Emergency in Context}


Steven Paget

Forthcoming in Small Wars and Insurgencies, 28:2, 2017. This is the post-print version and must not be copied or cited without permission.

The closer one examines how this victory was achieved the clearer it becomes that it came about in circumstances that were particular, indeed unique, to Malaya. ${ }^{89}$

\section{Milton Osborne}

The increasing US commitment to Vietnam in the 1960s inevitably led to commentators and policy makers looking back on the Malayan Emergency in order to extract relevant lessons. ${ }^{90}$ Since then, despite vociferous scholarly deliberation about the relevance of the Malayan Emergency, the quest to distil lessons for contemporary and future operations goes on unabated. The wider debate about whether the Emergency represents an exemplar for counter-insurgency operations is beyond the scope of this article, but Donald Mackay's conclusion is worthy of consideration:

There are individual lessons to be learnt, but the unique circumstances that allowed the colonial power to deal with the terrorist campaign so effectively that it never even got as far as being a truly insurgent war were just that-unique. It seems unlikely that they will ever be replicated at another time or in another place, and those who seek in Malaya a blueprint for counterinsurgency must look elsewhere. ${ }^{91}$

While the circumstances that led to the successful outcome of the Malayan Emergency may have been unique, the use of naval power was most certainly not. One of the 'individual lessons' despite being overlooked or dismissed in most accounts of the Malayan Emergency - was the use of NGS.

Firstly, the notion that NGS was merely 'mobile' or 'floating' artillery overlooks the significance of the capability. When land-based artillery was either unavailable or could not reach a target, NGS offered an important replacement capability. During the Emergency, it was noted that 'naval bombardments in support of Security Forces are... of the greatest value on those occasions where the targets are inaccessible to land artillery'. ${ }^{92}$ That lesson was far from new. During the prolonged counterinsurgency campaign to end resistance to Habsburg rule, AustroHungarian operations in Bosnia-Hercegovina were able to utilise naval gunfire support when other 
Steven Paget

Forthcoming in Small Wars and Insurgencies, 28:2, 2017. This is the post-print version and must not be copied or cited without permission.

firepower proved unavailable or insufficient. At Krivošije in 1882, rugged terrain limited the involvement of the mountain artillery batteries and led to naval bombardments taking on increasing significance. When the insurgents used stone buildings for cover, naval bombardments that were spotted with signal flags proved able to destroy the structures when the $70 \mathrm{~mm}$ mountain guns could not. ${ }^{93}$ The very fact that ships provide a floating gun platform is inherently relevant as the subsequent flexibility means that targets can be engaged that may not otherwise be feasible due to the absence or limitations of other capabilities.

Analyses of the Malayan Emergency have prompted questions about whether NGS was required at all. Grey argued that NGS missions were conducted because 'they were available rather than because they were strictly necessary, much less effective'. ${ }^{94}$ Although the necessity and effectiveness of NGS is contentious and, arguably, situationally dependent, the presence and flexibility provided by naval ships is significant. Ships were needed for the blockade and the fact that they could be used in a power projection role served as a force multiplier. The same was true of ships passing through the theatre, as demonstrated by the assertion about Newfoundland that: 'Not many ships can say that they have occupied themselves between ceremonial parade rehearsals by bombarding the enemy.' 95

The use of NGS must always be contextualised as a subsidiary element of a much larger naval role. During the Philippine-American War (1899-1902), it was noted that the United States Navy's blockade meant that it was not easy for the 'the insurgents to coordinate actions among themselves'. ${ }^{96}$ Max Boot has assessed that the combination of a blockade that prevented the import of arms and supplies, re-supply efforts and NGS ensured that the 'army could not have won without the navy'. ${ }^{97}$ NGS may not have been the primary naval role, but it was a welcome contribution to 
Steven Paget

Forthcoming in Small Wars and Insurgencies, 28:2, 2017. This is the post-print version and must not be copied or cited without permission.

the counterinsurgency campaign. It would seem only logical that if ships are present to conduct a range of tasks that they be equipped and trained to meet fire support requirements. NGS was not conducted during the Emergency because the ships were there. Rather, NGS could be provided when necessary because the ships were already there conducting other important missions.

Although NGS during the Emergency has sometimes been dismissed as harassment fire, it proved useful in that context in Malaya and in both earlier and later conflicts in diminishing the morale of enemy forces. Sam Sarkesian concluded that the Battle of Manila (1899) demonstrated that 'regardless of numbers and the protection of trenches and redoubts, the insurgent forces could not or would not stand up before the American forces, particularly when American attacks were supported by artillery and naval gunfire'. ${ }^{98}$ Following the Battle of Surabya in November 1945 during the British involvement in the Netherlands East Indies, Major-General Robert Mansergh, commander of the $5^{\text {th }}$ Indian Division, noted: 'The accurate and willing support of the RN and RAF has been a considerable factor in the success of this operation and has again earned the admiration and thanks of the ground forces. ${ }^{99}$ Given the willingness of a sizeable portion of the local population to engage in fighting, artillery support, NGS and air strikes were assessed to have been crucial as they had 'the effect of clearing the fighting area of a large proportion of the mob, leaving the field clear for the more organised force'. ${ }^{100}$

A use was even found for NGS during the Tanganyikan Army mutiny in 1964. Although firings against Colito barracks were discounted after consideration of the likely consequences, HMS Cambrian still provided a demonstration bombardment during the assault by 45 Commando, Royal Marines, in order to demoralise the enemy. ${ }^{101}$ Equally, while the use of harassment fire during the Vietnam War has often been deemed profligate, Captain E.E. Johnston, HMAS 
Steven Paget

Forthcoming in Small Wars and Insurgencies, 28:2, 2017. This is the post-print version and must not be copied or cited without permission.

Vendetta's Commanding Officer, declared in the midst of the conflict:

the purpose served by harassment fire as against the cost involved has been a matter of conjecture in my mind since the commencement of this deployment. It was therefore gratifying to hear a report from the spotter that a V.C. defector during interrogation had stated that his 'unit had become completely demoralised during the past two to three weeks because of the heavy mortars from the sea'. ${ }^{102}$

The effectiveness of harassment fire is notoriously hard to quantity and there was undoubtedly wastage during the Vietnam War, but that does not mean that the psychological effect of the weapon did not produce positive results under the right circumstances. Equally, the Malayan Emergency demonstrated that NGS also has the potential to improve the morale of friendly forces. NGS, like other aspects of firepower, can be particularly heartening for land forces when they are aware that their adversaries cannot rely on the same capabilities.

Just because NGS can be effective during small wars and insurgencies, does not mean that it will be or that it will not be used excessively. Certain conditions are necessary in order to maximise the efficiency of NGS. One account of intelligence during the Emergency surmised the 'contribution of intelligence' to NGS operations was 'not great', declaring that 'intelligence jigsaws were vastly incomplete'. ${ }^{103}$ The most successful NGS missions were those that were grounded in sound and timely intelligence. During the Vietnam War, RAN officers complained that a significant degree of harassment and interdiction fire was wasted as the targets were based on stale information. ${ }^{104}$ Conversely, Austro-Hungarian counterinsurgency operations in BosniaHercegovina during 1882 were intelligence-led and based on the reconnaissance of local resistance groups, which allowed troops to converge on the enemy with the support of a range of firepower. At Cattaro, for example, mountain artillery was usefully supplemented with bombardments by the 
Steven Paget

Forthcoming in Small Wars and Insurgencies, 28:2, 2017. This is the post-print version and must not be copied or cited without permission.

Austro-Hungarian Navy. ${ }^{105}$ As with all aspects of firepower, the availability of accurate intelligence enhances the likely effectiveness of NGS.

The selection of appropriate targets is also a necessary precursor to effective NGS. In the harassment role, it was discovered that in Malaya 'there was little differentiation, from the C.Ts point of view, between small and large calibre shells', which meant that aside from longer range of 6" guns, the use of cruisers for that purpose was deemed to be 'uneconomical'. ${ }^{106}$ The matching of appropriate targets to the capability was one of the clear lessons about NGS that emerged from the conflict. The same principle was demonstrated during the Vietnam War. Captain David Leach, Commanding Officer of HMAS Perth during the ship's second deployment to Vietnam, opined in 1968 that NGS was sometimes used against inappropriate targets. In one instance, Perth, with the assistance of two A4s in the spotting role, damaged a bridge, before it was subsequently obliterated by eight 5001 bombs dropped by the same aircraft. Captain Leach lamented: 'this I think clearly illustrates the way NGS with high muzzle velocity and inherent range spreads is being misused in this war on point targets which can be more efficiently dealt with by air ordnance'. ${ }^{107}$

In Malaya, the effectiveness of NGS was perceived to have been enhanced when it was conducted in conjunction with related ground action. Likewise, in Vietnam, it was noted that the usefulness of NGS could be negated if friendly troops did not conduct 'concerted drives to clear the area' ${ }^{108}$ In contrast, close coordination between land and naval forces was achieved during the Asturian Revolt in Spain in 1934 when revolutionaries 'barricaded' themselves in the workingclass areas of Gijón. ${ }^{109}$ With the revolutionary forces effectively besieged, the 8-inch guns of the cruiser Libertad shelled Gijón as a precursor to an aggressive and successful assault by the Army of Africa. ${ }^{110}$ Although there may be an occasional exception to the rule, such as the operation to 
Steven Paget

Forthcoming in Small Wars and Insurgencies, 28:2, 2017. This is the post-print version and must not be copied or cited without permission.

re-take South Georgia during the Falklands War when the bombardment by HM Ships Plymouth and Antrim was so extensive that it compelled the Argentine forces under Lieutenant Commander Alfredo Astiz to surrender before the fire plan could be completed, NGS is most effective when it is combined with land and/or air power. ${ }^{111}$

The lack of NGS during recent counterinsurgency operations is not representative of the overall trend. While it is now used much more sparingly, NGS remains a feature of contemporary operations. During the assault on the Al Faw Peninsula in Iraq in 2003, HM Ships Chatham, Marlborough and Richmond and HMAS Anzac fired 155 rounds during 17 missions. Over the course of Operation Ellamy - the 2011 intervention in Libya - British and French ships engaged in 50 NGS missions, firing over 500 rounds in the process.

Although the assault on the Al Faw was very much a conventional operation, parallels can be drawn in the use of NGS. During the 2003 Iraq War, coalition forces had not initially envisioned a need for NGS, but the presence of gun-equipped ships that were involved in maritime interception operations meant that the capability could be called upon when the requirement unexpectedly arose. The $155 \mathrm{~mm}$ artillery positioned on Bubyian Island was unable to reach the tip of the Al Faw and plans to use Landing Craft Air Cushion Class Hovercrafts to land light armour and artillery on the beach were scrapped in view of the threat posed by Iraqi mines. ${ }^{112}$ Competing demands for close air support and difficult flying conditions served to further enhance the significance of NGS being available.

The psychological element of NGS was also a key factor in its employment. As the Royal Marines advanced to contact, a call for fire with 'danger close' was placed to eradicate threats posed by fixed installations such as artillery and bunkers. Initial rounds were generally offset so 
Steven Paget

Forthcoming in Small Wars and Insurgencies, 28:2, 2017. This is the post-print version and must not be copied or cited without permission.

that they would fall close to, but not on the target; a tactic that was accompanied by the use of loud speakers to deliver messages with the intention being to induce surrenders, which generally proved to be successful. However, the kinetic effect of NGS was also demonstrated with the destruction of enemy artillery and structures. ${ }^{113}$ Although it would be easy to dismiss the Malayan Emergency as a historical anachronism, principles about the circumstances in which NGS is most likely to be effective are enduring. NGS is a blunt tool and can only ever play a limited role, but the contribution may be vital to those serving on land.

\section{Conclusion: A Situationally Dependent Capability}

Ucko and Robert Egnell have rightly noted: 'As the grievance and conditions from which insurgents draw their strength are usually social or political or economic in nature, it follows that defeating the insurgent group will typically require more than a merely military approach.' ${ }^{114}$ The military role, including the maritime contribution, will necessarily be limited. Although it was sometimes used inappropriately, naval power was relevant during the Malayan Emergency. As was the case in a variety of conflicts before and after the Malayan Emergency, naval forces made a number of important contributions, not least the conduct of a blockade. Ships were not deployed for the purpose of NGS, which was a subsidiary role, but that does not mean that it was not a welcome contribution under the right circumstances. The limitations of the capability and the challenges of the operating environment constrained the overall effect that NGS had on the outcome of the Emergency - although that conclusion was true of all elements of firepower given the nature of the campaign. Nevertheless, when used selectively, NGS was able to have a localised effect and contributed to the success of operations. When based on accurate intelligence, supported 
Steven Paget

Forthcoming in Small Wars and Insurgencies, 28:2, 2017. This is the post-print version and must not be copied or cited without permission.

by sufficient observation and directed against appropriate targets, NGS remains an effective capability.

Accurate fire against pinpoint targets during the Malayan Emergency was constrained by the limitations of technology and the challenges presented by the operating environment, but even then, it proved possible on occasion. Since the Emergency, NGS has been used to successfully engage fixed installations and fielded forces. However, the utility of NGS transcends its mere destructive effect. As the ships are not visible, there is no warning of bombardments and the intended targets generally will not have the opportunity to respond, NGS can have a devastating psychological effect. In demoralising the enemy, while at the same time boosting the morale of the supported arm and the ship's crew, NGS can provide an effect that cannot be quantified by any kind of damage assessment.

Conflicts since the Malayan Emergency, including in Iraq and Libya, have reinforced the notion that NGS still has a role to play, albeit limited. Firepower can be viewed through the metaphor of a 'Swiss Army Knife'. As there is no universal tool for every job, a range are provided in order to ensure effectiveness. In the case of small wars and insurgencies, more niche tools are often required. However, occasionally, situations will arise when a tried and trusted capability such as NGS can significantly aid the effort on land. When that opportunity arises, it is important that NGS can be effectively utilised.

\footnotetext{
${ }^{1}$ Short, The Communist Insurrection in Malaya, p.372.

${ }^{2}$ Ucko, "The Malayan Emergency," p.14.

${ }^{3}$ Miller, "An Unparalleled War and The Special Branch,” p.327.
} 
Steven Paget

Forthcoming in Small Wars and Insurgencies, 28:2, 2017. This is the post-print version and must not be copied or cited without permission.

\footnotetext{
${ }^{4}$ Dennis and Grey, Emergency and Confrontation, pp.69-70.

${ }^{5}$ Gentile, Wrong Turn, p.22.

${ }^{6}$ Drew, "Air Theory, Air Force, and Low Intensity Conflict," p.342.

${ }^{7}$ Corum, "On Airpower, Land Power, and Counterinsurgency," pp.93-94.

${ }^{8}$ Harris, "The Navy's Role in Confronting Irregular Challenges."

${ }^{9}$ Mumford, "Unnecessary or Unsung,” p.636.

${ }^{10}$ Corum, "On Airpower, Land Power, and Counterinsurgency," p.94.

${ }^{11}$ Murphy, "The Blue, Green, and Brown", p.63.

${ }^{12}$ Corum and Johnson, Airpower in Small Wars, p.1.

${ }^{13}$ Speller, Understanding Naval Warfare, p.8.

${ }^{14}$ Benbow, "Maritime Forces and Counter-insurgency," p.80.

${ }^{15}$ Hoffman, "The First Non-state Use of a Chemical Weapon in Warfare," p.468.

${ }^{16}$ Marks, "Counterinsurgency and Operational Art," p.181.

${ }^{17}$ Murphy, "The Blue, Green, and Brown," p.67.

${ }^{18}$ For more on the maritime role in Sri Lanka, see: Smith, "Maritime Interdiction in Sri Lanka's Counterinsurgency," p.448.

${ }^{19}$ Devitt, “The 'Navalization' of Ireland,” p.388.

${ }^{20}$ Benbow, "Maritime Forces and Counter-insurgency," p.82.

${ }^{21}$ Underwood, Waters of Discord, p.31; Meilinger, Airwar, p.194; Moon, Wellington's Two-Front War, p.175.

${ }^{22}$ Kurth, "The New Maritime Strategy," p.599.

${ }^{23}$ Imperial War Museum (IWM), Papers of Lieutenant General Sir Roger Bower, Director of Operations, Malaya, 'Review of the Emergency Situation in Malaya at the End of 1954', 10 January 1955.

${ }^{24}$ Coates, Suppressing Insurgency, p.169.
}

${ }^{25}$ For more information on the contributions of the Royal Air Force, Royal Australian Air Force and Royal New Zealand Air Force see: Postgate, Operation Firedog.

${ }^{26}$ Benbow, "Maritime Forces and Counter-insurgency," p.84; Tuck, "The Royal Navy and Confrontation," p.205.

${ }^{27}$ Directorate of Operations, Malaya, The Conduct of Anti-Terrorist Operations in Malaya, pp.12-13.

${ }^{28}$ Australian War Memorial (AWM), AWM 121, 402/A/2, 'Attachment of Her Majesty's Australian Ships to the Far East Fleet for Service with the Strategic Reserve', Undated.

${ }^{29}$ IWM, Papers of Lieutenant General Sir Roger Bower, Director of Operations, Malaya, 'Review of the Emergency Situation in Malaya at the End of 1954', 10 January 1955.

${ }^{30}$ IWM, Papers of Lieutenant General Sir Roger Bower, Lieutenant General Sir Roger Bower, 'Final Review of the Emergency in Malaya', 17 September 1957.

${ }^{31}$ The National Archives of the UK (TNA), AIR 20/10377, Director of Operations, Malaya, 'Review of the Emergency Situation in Malaya from June 1948 to August 1957', September 1957.

${ }^{32}$ Coates, Suppressing Insurgency, p.169.

${ }^{33}$ Peter Dennis and Jeffrey Grey have contended: 'There was no evidence to suggest that CTs were being smuggled into Malaya by sea routes, when overland trails, through the dense jungle that covered much of Malaya and which extended into the border areas with Thailand where the CTs found ready sanctuary, provided acceptable, if slow, lines of communication.' Dennis and Grey, Emergency and Confrontation, p.69; Smith, Counter-Insurgency Operations, p.35.

${ }^{34}$ Short, The Communist Insurrection in Malaya, p.372.

${ }^{35}$ Grey, "Naval Operations in Peripheral Conflicts," p.133.

${ }^{36}$ Short, The Communist Insurrection in Malaya, p.372.

${ }^{37}$ Jackson, The Malayan Emergency, p.36.

${ }^{38}$ TNA, AIR 20/10377, Director of Operations, Malaya, 'Review of the Emergency Situation in Malaya from June 1948 to August 1957', September 1957.

${ }^{39}$ IWM, Papers of Lieutenant General Sir Roger Bower, Director of Operations, Malaya, 'Review of the Emergency Situation in Malaya at the End of 1955', January 1956. 
Steven Paget

Forthcoming in Small Wars and Insurgencies, 28:2, 2017. This is the post-print version and must not be copied or cited without permission.

${ }^{40}$ Grey, "Naval Operations in Peripheral Conflicts," p.133.

${ }^{41}$ IWM, Papers of Lieutenant General Sir Roger Bower, Director of Operations, Malaya, 'Review of the Emergency Situation in Malaya at the End of 1956', January 1957.

${ }^{42}$ Short, The Communist Insurrection in Malaya, p.372; TNA, ADM 53/138066, 'H.M.S. Defender: Ship's Log, March 1954', March 1954.

${ }^{43}$ TNA, AIR 20/10375, Director of Operations, Malaya, 'Review of the Emergency Situation in Malaya at the End of 1955', January 1956.

${ }^{44}$ The vessels involved were: HM Ships Comus, Concord, Cossack, Newcastle and Opossum. TNA, ADM 1/26140, Office of Flag Officer, Malayan Area to Commander-in-Chief, Far East Station, 'Joint Operations Against Communist Terrorists in Kuala Langat (Operation "NASSAU”)', 3 November 1955.

${ }^{45}$ TNA, ADM 1/26140, Commander-in-Chief, Far East Station, to the Secretary of the Admiralty, 'Joint Operations Against Communist Terrorists in Malaya (Operations "NASSAU" and "REX")', 30 November 1955.

${ }^{46}$ Grey, "Naval Operations in Peripheral Conflicts," p.133.

${ }^{47}$ Directorate of Operations, Malaya, The Conduct of Anti-Terrorist Operations in Malaya, p.24; TNA, AIR 20/10375, Director of Operations, Malaya, 'Review of the Emergency Situation in Malaya at the End of 1955', January 1956.

${ }^{48}$ TNA, ADM 1/26140, Office of Flag Officer, Malayan Area to Commander-in-Chief, Far East Station, 'Operation Rex - Report', 17 November 1955.

${ }^{49}$ Ibid.

${ }^{50}$ TNA, ADM 1/26140, Commander-in-Chief, Far East Station, to the Secretary of the Admiralty, 'Joint Operations Against Communist Terrorists in Malaya (Operations "NASSAU" and "REX")', 30 November 1955.

${ }^{51}$ TNA, ADM 1/26140, Office of Flag Officer, Malayan Area to Commander-in-Chief, Far East Station, 'Operation Rex - Report', 17 November 1955.

${ }^{52}$ Ibid.

53 TNA, ADM 1/25556, Signal from H.M.S. Newfoundland to the Flag Officer, Second-in-Command, Far East Station, 'Operation Eclipse - Bombardment in Support of Security Forces Operating Against Communist Terrorists in the Peak District of Central Kedah', 15 June 1954.

${ }^{54}$ Ibid.

55 TNA, ADM 1/25556, Message from Second in Command, Far East Station, to Flag Officer, Malayan Area, 'Operation Eclipse - Bombardment in Support of Security Forces Operating Against Communist Terrorists in the Peak District of Central Kedah (The Commanding Officer, H.M.S. Newfoundland's Letter No.229/2 dated 15 June, 1954)', 15 June 1954.

${ }^{56}$ TNA, ADM 1/2555, Message from 56 Ground Liaison Section, RAF Station Butterworth, to Naval Liaison Officer, HQ Malaya, Kuala Lumpur, 'Op Reports - Operation Eclipse', 22 June 1954.

${ }^{57}$ TNA, ADM 1/25556, Message from HQ 1 Federal Division District, Taiping to HQ Malaya, 'Bombardment Kedah Peak by HMS Newfoundland', 3 July 1954.

${ }^{58}$ TNA, ADM 1/25556, Signal from H.M.S. Newfoundland to the Flag Officer, Second-in-Command, Far East Station, 'Operation Eclipse - Bombardment in Support of Security Forces Operating Against Communist Terrorists in the Peak District of Central Kedah', 15 June 1954.

${ }^{59}$ The Flag Officer, Malayan Area, conceded: 'inch to 1 mile maps of the coasts of Malaya, are maintained in the Chart Deport and are issued to ships on the Malayan ration. These are normally adequate for bombardments. It is agreed that larger scale maps are desirable where exceptionally high or steep terrain is involved. These are usually available from the Army and will be obtained for future bombardments of this nature.' TNA, ADM 1/25556, Message from Second in Command, Far East Station, to Flag Officer, Malayan Area, 'Operation Eclipse - Bombardment in Support of Security Forces Operating Against Communist Terrorists in the Peak District of Central Kedah (The Commanding Officer, H.M.S. Newfoundland's Letter No.229/2 dated 15 June, 1954)', 15 June 1954; TNA, ADM 1/25556, Signal from H.M.S. Newfoundland to the Flag Officer, Second-in-Command, Far East Station, 'Operation 
Steven Paget

Forthcoming in Small Wars and Insurgencies, 28:2, 2017. This is the post-print version and must not be copied or cited without permission.

Eclipse - Bombardment in Support of Security Forces Operating Against Communist Terrorists in the Peak District of Central Kedah', 15 June 1954.

${ }^{60}$ TNA, ADM 1/25556, Signal from H.M.S. Newfoundland to the Flag Officer, Second-in-Command, Far East Station, 'Operation Eclipse - Bombardment in Support of Security Forces Operating Against Communist Terrorists in the Peak District of Central Kedah', 15 June 1954.

${ }^{61}$ Pfennigwerth, Tiger Territory, p.61.

${ }^{62}$ AWM, AWM 78, 34/4, 'HMAS Anzac: Report of Proceedings, September 1956', 1 October 1956.

${ }^{63}$ AWM, AWM 78, 343/5, Part 1, 'HMAS Tobruk: Report of Proceedings, September 1956', 6 October 1956.

${ }^{64}$ Pfennigwerth, Tiger Territory, p.61.

${ }^{65}$ AWM, AWM 78, 300/4, 'HMAS Quickmatch: Report of Proceedings, January 1957’, 7 February 1957.

${ }^{66}$ AWM, AWM 78, 298/5, 'HMAS Queenborough: Report of Proceedings, January 1957', 3 February 1957.

${ }^{67}$ AWM, AWM 78, 34/5, 'HMAS Anzac: Report of Proceedings, July 1957', 2 August 1957.

${ }^{68}$ AWM, AWM 78, 343/5, Part 1, 'HMAS Tobruk: Report of Proceedings, August 1957', 5 September 1957.

${ }^{69}$ Newsinger, British Counterinsurgency, pp.77-78.

${ }^{70}$ Short, The Communist Insurrection in Malaya, p.370.

${ }^{71}$ Postgate, Operation Firedog, p.22.

${ }^{72}$ TNA, ADM 1/26140, Office of Flag Officer, Malayan Area to Commander-in-Chief, Far East Station, 'Joint Operations Against Communist Terrorists in Kuala Langat (Operation "NASSAU")', 3 November 1955.

${ }^{73}$ The term 'hate' was applied to ritualised forms of aggression and was particularly prominent during the First World War.

${ }^{74}$ TNA, ADM 1/26140, Office of Flag Officer, Malayan Area to Commander-in-Chief, Far East Station, 'Joint Operations Against Communist Terrorists in Kuala Langat (Operation "NASSAU”)', 3 November 1955.

${ }^{75}$ Ibid.

${ }^{76} \mathrm{Ibid}$.

${ }^{77}$ Jackson, The Malayan Emergency, p.78.

${ }^{78}$ A First World War memorandum was just as applicable during the Emergency: 'by constantly harassing the enemy... we can greatly improve the morale of our own troops and wear out and depress the enemy'. Ashworth, Trench Warfare, p.91.

${ }^{79}$ TNA, ADM 1/26140, Office of Flag Officer, Malayan Area to Commander-in-Chief, Far East Station, 'Operation Rex - Report', 17 November 1955.

${ }^{80}$ TNA, ADM 1/26140, Commander-in-Chief, Far East Station, to the Secretary of the Admiralty, 'Joint Operations Against Communist Terrorists in Malaya (Operations "NASSAU” and "REX")', 30 November 1955.

${ }^{81}$ TNA, ADM 1/26140, Office of Flag Officer, Malayan Area to Commander-in-Chief, Far East Station, 'Operation Rex - Report', 17 November 1955.

${ }^{82}$ Jackson, The Malayan Emergency, p.78.

${ }^{83}$ TNA, ADM 1/26140, Office of Flag Officer, Malayan Area to Commander-in-Chief, Far East Station, 'Operation Rex - Report', 17 November 1955.

${ }^{84}$ French, The British Way in Counter-Insurgency, p.44.

${ }^{85}$ Marston, "Lost and Found in the Jungle," p.96.

${ }^{86}$ Arnold, A Jungle of Snakes, p.178; Parker, The Gurkhas, p.235.

${ }^{87}$ For example, during Operation Inland, which was commenced north of Ipoh in March 1954, the Lincoln Bombers of No.1(B) Squadron Royal Australian Air Force were instructed to conduct bombing and strafing with the intention of driving the enemy into ambush positions. The same principle could be applied to NGS although the capability was not as effective in that regard. AWM, AWM 64 1/8, No.1(B) Squadron RAAF Operational Log-Malaya, February July 1954.

${ }^{88}$ TNA, ADM 1/25556, Message from Naval Liaison Officer, HQ Malaya, Kuala Lumpur, to Flag officer, Malayan Area, 'Report on Naval Bombardment - H.M.S. Newfoundland', 29 June 1954. 
Steven Paget

Forthcoming in Small Wars and Insurgencies, 28:2, 2017. This is the post-print version and must not be copied or cited without permission.

${ }^{89}$ Osborne, Getting the Job Done, p.12.

90 Tilman, "The Non-Lessons of the Malayan Emergency,” p.407.

${ }^{91}$ Mackay, The Malayan Emergency, pp.152-153.

92 TNA, ADM 1/26140, Office of Flag Officer, Malayan Area to Commander-in-Chief, Far East Station, 'Joint Operations Against Communist Terrorists in Kuala Langat (Operation “NASSAU”)', 3 November 1955.

${ }^{93}$ Schindler, "Defeating Balkan Insurgency," pp.546-547.

94 Grey, "Naval Operations in Peripheral Conflicts," p.133.

95 TNA, ADM 1/25556, Unknown author, 'Register No. M.267.215.54, Minute Sheet 1', 29 September 1954.

${ }^{96}$ Rabasa et al., Money in the Bank, p.11.

${ }^{97}$ Boot, The Savage Wars of Peace, p.128.

${ }^{98}$ Sarkesian, America's Forgotten Wars, p.169.

99 Jordan, “"A Particularly Exacting Operation'," p.107.

100 Jordan, “"A Particularly Exacting Operation'," p.108.

${ }^{101}$ Speller, "Limited War and Crisis Management," pp.167-168.

102 AWM, AWM 78, 352/9A, 'HMAS Vendetta: Report of Proceedings, January 1970', 1 February 1970.

${ }^{103}$ Pfennigwerth, Missing Pieces, p.195.

${ }^{104}$ Leach, "DDGs in Vietnam," p.341.

105 Schindler, "Defeating Balkan Insurgency,” p.546.

106 TNA, ADM 1/26140, Office of Flag Officer, Malayan Area to Commander-in-Chief, Far East Station, 'Joint Operations Against Communist Terrorists in Kuala Langat (Operation “NASSAU”)', 3 November 1955.

107 AWM, AWM 78, 292/6, 'HMAS Perth: Report of Proceedings, October 1968', 4 November 1968.

108 AWM, AWM 78, 292/6, 'HMAS Perth: Report of Proceedings, December 1968', 1 January 1969.

${ }^{109}$ Bunk, Ghosts of Passion, p.31.

${ }^{110}$ Black, Avoiding Armageddon, p.215; Álvarez, "The Spanish Foreign Legion,” p.210.

111 TNA, ADM 202/817, 148 (Meiktila) Commando Forward Observation Battery, Royal Artillery: Operation Corporate Report (Falklands Conflict), 1 July-31 July 1982.

112 Dutton and Waldhauser, "Operation Iraqi Freedom," p.10.

${ }^{113}$ For more on the conduct of NGS during the assault on the Al Faw Peninsular, see: Ingham, "Naval Gunfire Support for the Assault of the Al Faw Peninsular," pp.33-36.

${ }^{114}$ Ucko and Egnell, Counterinsurgency in Crisis, p.8. 
Steven Paget

Forthcoming in Small Wars and Insurgencies, 28:2, 2017. This is the post-print version and must not be copied or cited without permission.

\section{Bibliography}

Álvarez, José E. "The Spanish Foreign Legion during the Asturian Uprising of October 1934." War in History, 18:2 (2011), 200-224.

Arnold, James R. A Jungle of Snakes: A Century of Counterinsurgency Warfare from the Philippines to Iraq. New York: Bloomsbury Press, 2009.

Ashworth, Tony. Trench Warfare, 1914-1918: The Live and Let Live System. London: Pan Macmillan, 2000.

Benbow, Tim. "Maritime Forces and Counter-insurgency." Contemporary Security Policy, 28:1 (2007): 80-95.

Black, Jeremy. Avoiding Armageddon: From the Great War to the Fall of France, 1918-40. London: Bloomsbury, 2012.

Boot, Max. The Savage Wars of Peace: Small Wars and the Rise of American Power. New York: Basic Books, 2014.

Bunk, Brian D. Ghosts of Passion: Martyrdom, Gender, and the Origins of the Spanish Civil War. Durham: Duke University Press, 2007.

Coates, John. Suppressing Insurgency: An Analysis of the Malayan Emergency, 1948-1954. Boulder: Westview Press, 1992.

Corum, James S., "On Airpower, Land Power, and Counterinsurgency: Getting Doctrine Right," Joint Forces Quarterly, 49 (Second Quarter 2008): 93-97.

Corum, James S. and Wray R. Johnson, Airpower in Small Wars: Fighting Insurgents and Terrorists. Lawrence: University Press of Kansas, 2003.

Dennis, Peter, and Jeffrey Grey. Emergency and Confrontation: Australian Military Operations in Malaya and Borneo 1950-1966. Allen \& Unwin: Sydney, 1996.

Devitt, Jerome. “The 'Navalization' of Ireland: The Royal Navy and Irish Insurrection in the 1840s." The Mariner's Mirror, 101:4 (2015): 388-409.

Directorate of Operations, Malaya. The Conduct of Anti-Terrorist Operations in Malaya. Kuala Lumpur: Her Majesty's Stationery Office, 1958.

Drew, Dennis M. "Air Theory, Air Force, and Low Intensity Conflict: A Short Journey to Confusion." In The Paths of Heaven: The Evolution of Airpower Theory, edited by Phillip S. Meilinger, 321-355, Delhi: Lancer Publishers, 2000. 
Steven Paget

Forthcoming in Small Wars and Insurgencies, 28:2, 2017. This is the post-print version and must not be copied or cited without permission.

Dutton, Jim, and Tom Waldhauser, "Operation Iraqi Freedom: US/UK Operations." The RUSI Journal, 148:6 (2003): 8-14.

French, David. The British Way in Counter-Insurgency, 1945-1967. Oxford: Oxford University Press, 2011.

Gentile, Gian. Wrong Turn: America's Deadly Embrace of Counterinsurgency. New York: The New Press, 2013.

Grey, Jeffrey. "Naval Operations in Peripheral Conflicts: The Malayan Emergency (1948-1960) and Confrontation (1962-1966)." In Naval Power and Expeditionary Warfare: Peripheral Campaigns and New Theatres of Naval Warfare, edited by Bruce A. Elleman and S.C.M. Paine, 129-140, Oxford: Routledge, 2011.

Harris, Sinclair. "The Navy's Role in Confronting Irregular Challenges," U.S. Naval Institute Proceedings, 139:4 (April 2013). http://www.usni.org/magazines/proceedings/201304/professional-notes

Hoffman, Bruce. "The First Non-state Use of a Chemical Weapon in Warfare: The Tamil Tigers' Assault on East Kiran.” Small Wars \& Insurgencies, 20:3-4 (2009): 463-477.

Ingham, Lieutenant Commander Ivan. "Naval Gunfire Support for the Al Faw Peninsular." Journal of the Australian Naval Institute, 109 (2003): 33-36.

Jackson, Robert. The Malayan Emergency \& Indonesian Confrontation: The Commonwealth's Wars, 1948-1966. Barnsley: Pen \& Sword, 2014.

Jordan, David. “"A Particularly Exacting Operation': British Forces and the Battle of Surabaya, November 1945.” Small Wars \& Insurgencies, 11:3 (2000): 89-114.

Kurth, James. "The New Maritime Strategy: Confronting Peer Competitors, Rogue States, and Transnational Insurgents.” Orbis (Fall 2007): 585-600.

Leach, David. "DDGs in Vietnam: HMAS Perth, 19 September 1968 to 19 April 1969." In Reflections on the RAN, edited by T.R. Frame, J.V.P. Goldrick and P.D. Jones, 338-342, Kenthurst: Kangaroo Press, 1991.

Mackay, Donald. The Malayan Emergency, 1948-60: The Domino That Stood. London: Brassey's, 1997.

Marks, Thomas A. "Counterinsurgency and Operational Art." Low Intensity Conflict \& Law Enforcement, 13:3 (2005): 168-211. 
Steven Paget

Forthcoming in Small Wars and Insurgencies, 28:2, 2017. This is the post-print version and must not be copied or cited without permission.

Marston, Daniel. "Lost and Found in the Jungle: The Indian and British Army Jungle Warfare Doctrines for Burma 1943-5, and the Malayan Emergency, 1948-60." In Big Wars and Small Wars: The British Army and the Lessons of War in the $20^{\text {th }}$ Century, edited by Hew Strachan, 84114, Oxford: Routledge, 2006.

Meilinger, Phillip S. Airwar: Theory and Practice. London: Frank Cass, 2005.

Miller, Harry. "An Unparalleled War and The Special Branch." In Terrorism: Critical Concepts in Political Science, Volume II: The Second or Anti-Colonial Wave, edited by David C. Rapoport, 319-337. Oxford: Routledge, 2006.

Moon, Joshua. Wellington's Two-Front War: The Peninsular Campaigns, at Home and Abroad, 1808-1814. Norman: University of Oklahoma Press, 2011.

Mumford, Andrew, "Unnecessary or Unsung? The Utilisation of Airpower in Britain's Colonial Counterinsurgencies.” Small Wars \& Insurgencies, 20:3-4 (2009): 636-655.

Murphy, Martin N. "The Blue, Green, and Brown: Insurgency and Counter-insurgency on the Water." Contemporary Security Policy, 28:1 (2007): 63-79.

Newsinger, John. British Counterinsurgency (2 ${ }^{\text {nd }}$ Edition). Basingstoke: Palgrave Macmillan, 2015.

Osborne, Milton. Getting the Job Done: Iraq and the Malayan Emergency. Sydney: Lowy Institute, 2005.

Parker, John. The Gurkhas: The Inside Story of the World's Most Feared Soldiers. Chatham: Headline Book Publishing, 2005.

Pfennigwerth, Ian. Missing Pieces: The Intelligence Jigsaw and RAN Operations from 1939-71. Canberra: Sea Power Centre-Australia, 2008.

Pfennigwerth, Ian. Tiger Territory: The Untold Story of the Royal Australian Navy in Southeast Asia from 1948 to 1971. Dural: Rosenberg, 2008.

Postgate, Malcolm R. Operation Firedog: Air Support in the Malayan Emergency. London: Her Majesty's Stationary Office, 1992.

Rabasa, Angel, Lesley Anne Warner, Peter Chalk, Ivan Khilko and Paraag Shukla. Money in the Bank: Lessons Learned from Past Counterinsurgency (COIN) Operations. Santa Monica: RAND, 2007.

Sarkesian, Sam C. America's Forgotten Wars: The Counterrevolutionary Past and Lessons for the Future. Westport: Greenwood Press, 1984. 
Steven Paget

Forthcoming in Small Wars and Insurgencies, 28:2, 2017. This is the post-print version and must not be copied or cited without permission.

Scales Jr., Robert H. Fire Power in Limited War. Novato: Presidio Press, 1995.

Schindler, John. "Defeating Balkan Insurgency: The Austro-Hungarian Army in BosniaHercegovina, 1878-8.” Journal of Strategic Studies, 27:3 (2004): 528-552.

Short, Anthony. The Communist Insurrection in Malaya, 1948-1960. London: Frederick Muller Limited, 1975.

Smith, E.D. Counter-Insurgency Operations: 1, Malaya and Borneo. London: Ian Allan, 1985.

Smith, Justin O. "Maritime Interdiction in Sri Lanka's Counterinsurgency." Small Wars \& Insurgencies, 22:3 (2011): 448-466.

Speller, Ian. "Limited War and Crisis Management: Naval Aviation in Action from the Korean War to the Falklands Conflict." In British Naval Aviation: The First 100 Years, edited by Tim Benbow, 151-176, Farnham: Ashgate, 2011.

Speller, Ian. Understanding Naval Warfare. Abingdon: Routledge, 2014.

Tilman, Robert O. “The Non-Lessons of the Malayan Emergency.” Asian Survey, 6:8 (1966): 407419.

Tuck, Chris. "The Royal Navy and Confrontation, 1963-66." In British Naval Strategy East of Suez, 1900-2000: Influence and Actions, edited by Greg Kennedy, 199-220, Oxford: Routledge, 2005.

Ucko, David H. "The Malayan Emergency: The Legacy and Relevance of a Counter-Insurgency Success Story.” Defence Studies, 10:1 (2010): 13-39.

Ucko, David H. and Robert Egnell, Counterinsurgency in Crisis: Britain and the Challenges of Modern Warfare. New York: Columbia University Press, 2013.

Underwood, Rodman L. Waters of Discord: The Union Blockade of Texas during the Civil War. Jefferson: McFarland, 2003. 